DOI: $10.15372 / \mathrm{HSS} 20150408$

УДК 94 (47).073

\title{
И.П. КАМЕНЕЦКИЙ
}

\section{ГЕНЕРАЛЫ СКАЛОНЫ В РОССИИ (1735-1812 Гг.)}

\author{
Иван Павлович Каменецкий, \\ канд. ист. наук, старший научный сотрудник, \\ Институт истории ИИ СО РАН, \\ РФ, 630090, Новосибирск, ул. Николаева, 8, \\ e-mail: kameneckiiiwan@mail.ru
}

\begin{abstract}
В статье освещен жизненный путь и ратный подвиг героя Отечественной войны 1812 г. - генерала А.А. Скалона и его отца. Рассмотрены обстоятельства появления его предков - французов в России, их военная и административная служба. Показано, что карьерный рост А. Скалона произошел в правление Павла I, стремившегося к переустройству русской армии. На становление личностных черт и командных качеств будущего генерала оказали влияние добросовестная служба его близких родственников, нелегкие условия сибирского пограничья, а также учеба в составе «образцовой команды» в Петербурге.

Будучи шефом Иркутского полка, А. Скалон проявил себя заботливым и требовательным военачальником. Благодаря его авторитету и организаторским способностям была осуществлена успешная передислокация сибирских полков на западные рубежи России. При обороне Смоленска Скалон был смертельно ранен и похоронен по личному распоряжению Наполеона.
\end{abstract}

Ключевые слова: первые Скалоны в России, служба А. Скалона в Сибири, Иртышская линия, переход на запад, Смоленское сражение

\section{I.P. KAMENETSKIY}

GENERALS SKALON IN RUSSIA (1735-1812)

Ivan P. Kamenetskiy, Candidat of Historical Sciences, Senior Research Fellow, Institute of History SB RAS,

8, Nikolaev Str., Novosibirsk, 630090, Russia, e-mail: kameneckiiiwan@mail.ru

The paper is aimed at describing the military service of Generals Skalon, father and son who served in Russia in 1735-1812. This subject has not been scrutinized by scholars. Analysis of the new archival sources and use of a historical-biographical research method allowed to deepen understanding of the military and administrative activities of the first generations of the Scalons in Russia; to show their participation in the military campaigns of the XVIII century, their service in the Siberian fortified lines, their fight against Napoleon's invasion and other important events. A.A. Skalon was born in 1767 in the Biisk fortress into a family of the military, former French emigrants. In recognition of his father's services at the age of eight he was enlisted as a private in a squadron of the Life-Guards Preobrazhensky Regiment. Formation of personality and leadership potential of the future general was shaped by the faithful service of his close relatives, the tough conditions of the Siberian frontier as well as his study in the "model team" in St. Petersburg. As a chief of the Irkutsk Regiment A. Skalon proved himself a caring and demanding military leader while being different from other commanders in that he was unselfish and struggled against all sorts of abuses. The Siberian regiments were successfully relocated to the western borders of Russia owing to his authority and organizational abilities. The Dragoon Brigade under Skalon's command opposed the Napoleon's aggression from the first days of the war. While fulfilling an assigned task during the defense of Smolensk Skalon was fatally wounded and buried upon the order of Napoleon.

Key words: the first Scalons in Russia, A. Skalon's service in Siberia, Irtysh line, marching westward, the Battle of Smolensk.

Жизненный путь и ратный подвиг героя Отечественной войны 1812 г., генерала Антона Антоновича Скалона (1767-1812) лишь частично отражены в исторической литературе. В изучении его биографии имеется еще немало «белых пятен» и неточных сведений, не позволяющих в полной мере воссоздать портрет генерала, погибшего одним из первых русских военачальников в начальный период войны при обороне Смоленска.

Основным источником сведений о жизни А. Скалона и его службе долгое время являлась изданная в 1902 г. работа Е. Альбовского, посвященная исто- 
рии Иркутского драгунского полка [1]. Приведенные в ней данные, дополненные некоторыми сведениями, были представлены в краеведческих работах Н.Д Ростова [2, с. 43] и С.И. Исупова [3, с. 26-32]. Использование новых архивных источников и трудов его современников позволяет значительно расширить представления о военной и административной деятельности первых поколений Скалонов в России: участии их в военных компаниях XVIII в., службе на Сибирских укрепленных линиях, борьбе с нашествием Наполеона и т. п.

Прадедом будущего героя войны 1812 г. А. Скалона был Юрий де Скалон, происходивший из гугенотской французской семьи провинции Лангедок. В конце XVII в. в связи с притеснениями протестантов его семья переселилась в Швецию. В разгар Северной войны в 1710 г. он и его сыновья перешли на русскую службу, предварительно приняв православие. Один из сыновей Ю. Скалона - Даниил - состоял при русском посольстве в Копенгагене, был флигель-адъютантом при князе Трубецком, затем в чине подполковника служил в Киевском драгунском полку [1, с. 106].

Его сын Антон Данилович родился и вырос уже в России. В сохранившемся формулярном списке нашло отражение его продвижение по служебной лестнице и участие в ряде важных военных компаний. В 1735-1736 гг. он участвовал в польском и крымском походах, где отличился при штурме Перекопской линии, а также в сражениях под Бахчисараем и в местечке Карасеве. В 1737-1739 гг. в чине подпоручика сражался в молдавских землях, где также отличился при взятии турецкого ретраншемента в сражении при г. Хотине ${ }^{1}$. Семилетнюю войну А. Скалон встретил в чине премьер-майора, а завершил полковником. Ему довелось участвовать в основных событиях войны с Пруссией: сражении при р. Прегель, местечках Дрезине, Фридрикберхе, Егерсдорфе, Цорндорфе, взятии Берлина. Во всех «указанных баталиях», по мнению начальства, он «храбро и неустрашимо поступал». 19 июня 1761 г. в бою при Кастьянах попал в плен, но спустя полгода при размене военнопленных был освобожден и вновь вернулся в строй ${ }^{2}$.

С восшествием на престол Екатерины II начинается сибирский период его военной биографии. Полковника А. Скалона, с учетом его боевого опыта, знания фортификации и топографии направили в 1763 г. в распоряжение сформированного Сибирского корпуса, размещенного на укрепленных линиях Южной Сибири. Здесь он был назначен командиром одного из драгунских полков, переведенных на линии из Центральной России, затем - командиром драгунской бригады, состоявшей из Луцкого, Суздальского и Вологодского полков, расквартированных в крепостях и форпостах Иртышской линии ${ }^{3}$. Наряду с командованием полками

${ }^{1}$ Российский государственный военно-исторический архив (РГВИА). Ф. 490. Оп. 3. Ед. хр. 106. Л. 236-236 об.

2 Там же. Д. 127. Л. 450-457, 758 об. -759.

3 Там же. Л. 457.
Скалон активно участвовал в проектировании и создании новой Колывано-Кузнецкой линии, призванной обезопасить юго-восточные рубежи Сибири от притязаний Цинского Китая. Под его руководством во владениях бывшей Джунгарии была усовершенствована и укреплена система пограничных сооружений, возведенных на Иртыше еще в 1730-1740-е гг., осуществлен перенос Ямышевской и Семипалатной крепостей, основана Ануйская и Катунская крепости [4, с. 30-32].

В 1774 г. по приказу командующего сибирскими войсками генерал-поручика И. Деколонга он организует вооруженную борьбу с пытающимися прорваться в Западную Сибирь отрядами пугачевцев и наносит им ряд тяжелых поражений в уральских провинциях. За «усмирение пугачевского бунта» драгунский генерал в 1775 г. был пожалован орденом Святой Анны I степени, а через год А. Скалона-старшего произвели в генерал-поручики и назначили командующим Сибирским корпусом [1, с. 106-107].

По свидетельству современников, на новом посту он показал себя рачительным военным администратором, который заботился не только о безопасности, но и хозяйственном обустройстве Сибирских линий. При нем началось интенсивное заселение и земледельческое освоение приграничных районов Верхнего Прииртышья и Верхнего Приобья. А. Скалон немало заботился об установлении мирных, взаимовыгодных отношений с местными народами, хозяйственном освоении пограничных районов юга Западной Сибири. По некоторым источникам ему принадлежала инициатива в составлении одного из первых в России русско-киргизских словарей-разговорников, который во многом облегчил общение с казахскими народами, проведены первые опыты по заведению пчеловодства, распространившиеся позднее по всей Южной Сибири. Умер А. Скалон в 1777 г. во время инспекторской поездки в Усть-Каменогорскую крепость, где и был погребен с необходимыми воинскими почестями.

Названный его именем сын, Антон Антонович Скалон, родился в Бийской крепости в 1767 г. За заслуги отца в возрасте восьми лет его зачислили рядовым в роту лейб-гвардии Преображенского полка, где капитаном состоял сам наследник престола - цесаревич Павел. Это обстоятельство, очевидно, способствовало впоследствии знакомству будущего героя 1812 года с новым императором. До своего совершеннолетия (16 лет) будущий защитник Смоленска находился под опекой матери, которая дала ему необходимое домашнее образование. В его формуляре указано, что он «знает русский, немецкий и арифметику». В 16 лет Скалон младший был произведен в поручики и назначен в Сибирский, затем в Иркутский драгунский полк. Проявив усердие в службе, он быстро получил очередные чины капитана и майора, занимая при этом должность эскадронного командира [1, с. 106-107].

Армейская служба А. Скалона круто изменилась с началом правления Павла I, приложившего немало усилий к новому устройству русской армии, которое сопровождалось не всегда удачными прусскими за- 
имствованиями и собственными его нововведениями. В 1798 г. по указу императора майор Скалон в составе «образцовой команды», в которую входили молодые, наиболее отличившиеся офицеры, был направлен в Петербург для изучения нового порядка несения службы и воинских артикулов. Своим старанием и глубоким знанием армейских артикулов он обратил на себя внимание самого императора, придававшего военной службе особое значение. По всей видимости, отдельные, далеко не худшие, принципы и образцы павловской воинской школы - строгое следование уставам и выполнению своих обязанностей, требовательность в сочетании с заботой о подчиненных, личное бескорыстие и борьба с разного рода злоупотреблениями - были им глубоко усвоены, что оказало влияние на становление личностных черт и командных качеств будущего генерала. Заметим попутно, что кратковременное правление Павла I было отмечено некоторым улучшением положения нижних армейских чинов, положение же офицеров, преимущественно выходцев из дворян, наоборот, ухудшилось, и это не могло не вызвать у них недовольства проводимой императором политикой реформирования русской армии $[5$, c. $132-136]$.

Вскоре добросовестному сибирскому офицеру была пожалована анненская шпага, его произвели в подполковники и назначили командиром Иркутского полка. В 1799 г. он - уже полковник, а в 1800 г. - генерал-майор, исполняющий, учрежденную Павлом новую должность - шефа Иркутского полка.

На долю Скалона-младшего выпало более скромное, хотя и не менее ответственное предназначение обеспечить охрану и безопасность одного из участков русской границы в Южной Сибири. В его подчинении находилось около 2 тыс. плохо обученных драгун (в 1787 г. штат полка насчитывал 1765 чел.), большая их часть была рекрутирована из сибирских крестьян. Воинские подразделения были распределены и размещены по наскоро возведенным и разбросанным укреплениям Иртышской линии, простиравшейся от крепости Усть-Каменогорской до Бийска, отдельный эскадрон нес службу на китайской границе за Байкалом [1, с. 103].

Основными задачами вверенного А. Скалону полка являлись защита огромной протяженности границы от неприятеля, пресечение нападений и грабежей от степных киргизов, охрана торговых путей и борьба с контрабандой.

Несение воинской службы в Сибири, особенно на ее окраинах, всегда было не престижным и нелегким занятием. Служба здесь не была связана с участием в военных компаниях и блестящими победами, достигнутыми Россией в этот период на западе, в которых отличились предки Скалона. Соответственно, не ожидалось дальнейшего продвижения по службе, высоких наград и общественного признания. Отмечая непривлекательный характер несения службы на линии, Е. Альбовский справедливо заметил: «Эта служба линейных полков, никем не ценимая, малоизвестная, не могла по своей тягости сравняться со службой, стоявших в России» [1, с. 115].

Выполнение различных служб затруднялась не только малочисленностью линейных гарнизонов и их удаленность друг от друга, но и суровыми климатическими условиями русско-казахского пограничья. По свидетельству глубокого знатока казахской степи, современника Скалона А. Левшина, сильные бураны зимой и песчаные бури летом нередко поглощали целиком деревни и застигнутых стихией в необжитой степи людей и животных. По его словам, летом воздух в степи достигал такой высокой температуры, что «к железу, раскаленному солнцем, нельзя было прикоснуться рукой, а в песке можно было испечь яйца» [6, с. 7-9]. Зимой от жестоких морозов нередко гибли люди и животные.

О трудностях несения гарнизонной и разъездной службы на Сибирской линии сохранилось немало и других свидетельств. 17 января 1755 г. командующий линиями генерал-поручик И. Веймарн писал сибирскому губернатору В. Мятлеву: «Казаки службами чрезвычайно утруждены ... собственные их лошади почти ежегодно валятся и от покупки тех лошадей недешевыми ценами те казаки в неоплатные долги и в крайнюю нужду приходят» ${ }^{4}$. В конце XVIII в. материальное положение военных чинов линейных войск в мало обжитом крае оставалось по-прежнему низким: «Жители здешние, коих большая часть отставных солдат и разночинцев также и служивых вообще суть бедна и едва снискивают себе пропитание, потому что здесь нет никаких рукоделий», - сообщал один из современников Скалона [7, с. 851-853].

Несмотря на все тяготы и рутинность несения линейной службы, молодой генерал успешно справлялся со своими обязанностями, проявив себя как требовательный, взыскательный, но в то же время справедливый начальник. Так, по его указанию было проведено тщательное расследование обстоятельств гибели унтер-офицера Топоркова, получившего за незначительную провинность 150 ударов розгами. Полковые офицеры пытались скрыть это происшествие и представить смерть потерпевшего как следствие его болезни. Чтобы установить истинную причину смерти, по приказу Скалона тело Топоркова было вырыто и проведено медицинское освидетельствование. В результате по представлению Скалона виновник в смерти подчиненного майор Козловский за жестокое обращение к нижним чинам был предан военному суду, разжалован и исключен из службы $[1$, с. 136].

Для сравнения укажем, что его предшественник командующий сибирскими войсками в 1760-е гг. генерал-лейтенант К. Фрауендорф печально прославился жестокими наказаниями солдат и всех провинившихся. По свидетельству несшего в то время линейную службу капитана И. Андреева, «Он, Фрауендорф, столько был жесток, немилосерд, а лучше сказать мучитель, что не устыдился одного дня до обеда пересечь плеть-

\footnotetext{
${ }^{4}$ Исторический архив Омской обл. Ф. 366. Оп. 1. Д. 19. Л. 1-5.
} 
ми, кошками, при своем присутствии, где должен был слушать вопль иногда и невинных, до 110 человек» $[8$, c. 77$]$.

Известно также, что Скалон сделал выговор и представление о возмещении ущерба командиру полка полковнику Головачеву за нарушение им противопожарных мер, в результате которых сгорело 3 обывательских дома и конюшня с 53 лошадьми. Он также боролся с незаконной контрабандой с киргизами, которую нередко вели офицеры его полка, и другими злоупотреблениями на службе.

Очевидно, требовательность Скалона, его честное служение делу и личное бескорыстие не всегда приходились по душе как вышестоящему начальству, так и отдельным офицерам полка, которые видели в нем карьерного выдвиженца Павла I и приверженца его строгих армейских порядков. Возможно, это обстоятельство, а также семейные дела (в 1801 г. Скалон женился на дочери омского коменданта бригадира А. Клавера) и стали причинами его добровольной отставки. В конце ноября 1802 г. Скалон «сдал полк в отличном порядке», вышел в отставку «с правом ношения мундира, но без пенсиона» и уехал с семьей в Курскую губернию, где, очевидно, было родовое поместье жены, так как наличие у него собственности в формуляре не отмечено [1, с. 107].

Но его пребывание в отставке было непродолжительным. Обострение обстановки на западных рубежах России, вызванное победоносными войнами Наполеона в Европе, потребовало от военного ведомства призыва пригодных к службе отставных офицеров и генералов. В апреле 1806 г. Скалон был отозван и вновь назначен шефом Иркутского полка, который находился к этому времени в «расстроенном состоянии». По утверждению Е. Альбовского, Скалон остался недоволен направлением его на прежнее место службы, но ведавший назначениями командного состава генерал X. Ливен якобы заявил ему: «Вы назначаетесь для приведения его (полка) в отличное устройство, в каком вы оставили полк сей» $[1$, с. 166].

По прибытии на место службы Скалону пришлось срочно принимать меры по укреплению дисциплины, устранению недостатков, допущенных прежним командиром - генерал-майором Ф. Сухаревым. Наряду с наведением порядка в своем полку до прибытия в Сибирь генерала Г. Глазенапа ему пришлось также исполнять обязанности начальника 24-й сибирской дивизии, прославившейся позднее в Бородинском сражении.

1808 г. внес новые перемены в привычную армейскую жизнь Скалона. После заключения непрочного Тильзитского мира правительством были приняты меры по укреплению западной границы империи. Последовало решение о выводе из Сибири линейных войск и артиллерийских частей для усиления Западной армии. В декабре 1807 г. Государственный Совет распорядился о передислокации всех армейских полков Сибири на запад и подчинении их 1-й Западной армии. Скалону было поручено вывести из Сибири на Украину в Волынскую губернию три полка, объ- единенных в драгунскую бригаду - Иркутский, Сибирский и Оренбургский.

Перемещение большого контингента войск на огромное расстояние, подавляющая часть которых не подчинялась ранее Скалону, к тому же оторванных от семей и родных мест, было нелегкой задачей даже для испытанных в боях полководцев. Но, несмотря на все трудности длительного и утомительного перехода, задача была успешно решена. Переход сибиряков на новое место дислокации начался 18 сентября 1808 г. и завершился в сентябре 1809 г. В течение года драгуны благополучно преодолели расстояние почти в 5 тыс. верст, сделав лишь двухмесячную остановку в г. Чистополе Казанской губ. Во время марша полки не потеряли ни одного человека, дезертировавшего или отставшего по болезни, не было совершено дисциплинарных нарушений и проступков по отношению к местному населению. В официальной реляции о благополучном переходе полков командование отмечало: «Сей марш исполнен был в отличном порядке, с особым сбережением нижних чинов и всех полковых имуществ». Высоко ценивший исполнительную дисциплину в войсках военный министр А. Аракчеев на этом документе начертал резолюцию: «Генерал Скалон восхищения и награды достоин» [3, с. 28]. За успешное осуществление похода, сбережение людей и лошадей Скалон был удостоен ордена Святого Владимира 3-й степени.

По мнению Е. Альбовского, полки Скалона находились в резерве 1-й Западной армии и не принимали участия в боевых действиях в начальный период войны. Однако в «Боевом календаре: ежедневнике Отечественной войны 1812 года», содержащем перечень всех боевых столкновений с 4 июня по 31 августа 1812 г., приводятся сведения об участии Иркутского и Сибирского полков в упорных и ожесточенных сражениях уже в первые дни войны.

Согласно данным «Боевого календаря», 17-18 июня 1812 г. бригада Скалона в составе 6-го пехотного корпуса генерала Дохтурова 1-й армии вела тяжелые арьергардные бои против превосходящих сил французской армии при г. Ошмяны и местечке Неменчине Виленской губ.

В начале июля отдельный кавалерийский отряд Скалона в составе Сибирского, Иркутского драгунских полков и вошедшего в его подчинение Мариупольского гусарского полка и батальона 40-го Егерского полка сдерживал врага при переправе через р. Десну, прикрывая отход основных сил армии по большой Витебской дороге. 13-15 июля Иркутский и другие драгунские полки вместе с различными частями 1-й армии под командованием графа П. Палена участвовали в ряде сражений под г. Витебском [9, С. 67-68, С. 148].

Особенно отличились драгуны Скалона при обороне Смоленска, где 5 (12) августа состоялось ожесточенное сражение, длившееся 13 часов. По свидетельству очевидцев, это сражение «было одним из самых упорных, продолжительных и кровопролитных и в этом отношении оно немного уступает 
сражению 26 августа при сем Бородине» [9, с. 317]. Оборону города обеспечивал усиленный другими подразделениями корпус генерала Д. Дохтурова, насчитывавший до 30 тыс. чел., которому противостояла более 180 тысячная армия Наполеона. Задачей корпуса стало удержание неприятеля для обеспечения организованного отхода объединенных под Смоленском 1-й и 2-й русских армий.

Во время битвы за Смоленск драгуны А. Скалона вместе с батарейной ротой полковника Д. Апушкина защищали позиции у Молоховских ворот в Рачевском предместье крепости, прикрывая отход своей артиллерии и егерей в город. Подвергаясь непрекращающимся атакам конной дивизии Брюйера и корпуса маршала Нея, сибирские и другие полки несли тяжелые потери. Чтобы выиграть время для своевременного отвода русских подразделений А. Скалон предпринял неожиданную для противника контратаку драгунских эскадронов на левый вражеский фланг. Этот отвлекающий маневр сорвал попытку французов с ходу на плечах русских воинов ворваться в Смоленск и позволил обороняющимся сохранить свою артиллерию, занять более выгодную позицию за стенами Смоленского кремля. При выполнении поставленной задачи А. Скалон погиб от разорвавшейся рядом гранаты ${ }^{5}$.

По данным Е. Альбовского, тело генерала было найдено французами 6 августа и погребено по личному приказу и в присутствии Наполеона у Королевского бастиона Смоленской крепости со всеми воинскими почестями. Сто лет спустя по инициативе внуков генерала на месте погребения героя войны 1812 г. будет воздвигнут мраморный обелиск. Добавим к этому, что его потомки - сыновья, внуки и правнуки продолжили ратную и гражданскую службу на благо России, достигнув при этом немалых успехов на военном и другом поприще. Но изучение их жизнедеятельности является уже предметом других исследований.

\section{СПИСОК ЛИТЕРАТУРЫ}

1. Альбовский Е. История Иркутского драгунского полка Минск, 1902. 342 с.
2. Ростов Н.Д. Земли алтайской верные сыны. Из истории доблести и чести воинской сибирских полков. Барнаул: Изд-во Алтайского ТГУ, 2005. 296 с.

3. Исупов С.И. Потомки крестоносцев в Байской крепости или Судьба героя 1812 г. // Избранные страницы: клубу любителей алтайской старины - 20 лет. Барнаул, 2011. С. 22-32.

4. Огуриов А.Ю. Иртышская пограничная линия // Кузнецкая старина. Новокузнецк, 1999. Вып. 3. С. 19-35.

5. Эйдельман Н.Я. Грань веков. Политическая борьба в России. Конец XVIII - начало ХIX столетия. М.: Мысль, 1982. 306 с.

6. Левшин $A$. Описание киргиз-казачьих и киргиз-кайсацких орд и степей. СПб., 1832. Ч. 1. 357 с.

7. Щекатов А., Максимович Л. Словарь Географический Российского государства. М., 1804. Ч. III. 420 с.

8. Андреев И. Домовая летопись, писанная капитаном Иваном Андреевым в 1789 году. М.: «Книга по требованию», 2012. 108 с.

9. Боевой календарь: ежедневник Отечественной войны 1812 года // Труды Моск. отд. Императорского Русского военно-исторического общества. М., 2012. Т. 4. 662 с.

\section{REFERENCES}

1. Albovskiy Ye. History of the Irkutsk Dragoon Regiment. Minsk, 1902, 342 p. (In Russ.)

2. Rostov N.D. Faithful Sons of the Altai Land. From the History of Military Valour and Honor of the Siberian Regiments. Barnaul: Altai Technical State Univesity Press, 2005, 296 p. (In Russ.)

3. Isupov S.I. Descendents of the Crusaders in the Biysk Fortress or the Fate of a Hero of 1812. Selected Pages: $20^{\text {th }}$ Anniversary of the Club of Admirers of Antiquity. Barnaul, 2011, pp. 22-32 (In Russ.)

4. Ogurtsov A.Yu. Irtysh Fortified Line. Kuznetskaya Starina. Novokuznetsk, 1999, Issue 3, pp. 19-35 (In Russ.)

5. Eidelman N.Ya. Edge of Ages. Political Struggle in Russia. Late XVIII - Early XIX Centuries. Moscow: Mysl, 1982, 306 p. (In Russ.)

6. Levshin A. Description of Kirgiz-Cossack and Kirgiz-Kaisak Hordes and Steppes. SPb., 1832, part. 1. 357 p. (In Russ.)

7. Shchekatov A., Maksimovich L. Geographical dictionary of the Russian State. Moscow, 1804, part III, 420 p. (In Russ.)

8. Andreev I. Home Chronicle Written by the Captain Ivan Andreyev in 1789. Moscow: Publishing House "Kniga po trebovaniyu", 2012, 108 p. (In Russ.)

9. Battle Calendar of the Patriotic War of 1812. Trudy Moskovskogo Otdela imperatorskogo Russkogo Voenno-Istoricheskogo obshchestva. Moscow, 2012, vol. 4, 662 p. (In Russ.)

Статья принята редакцичей 02.11.2015

${ }^{5}$ РГВИА.Ф. 103. Оп. 208. Св. 45. Д. 2. Л. 349 об. 